\title{
Melt inclusion insights on rhyolites proposed as a source of economic lithium in Clayton Valley, Nevada
}

REGINA M. KHOURY ${ }^{1}$, CELESTINE N. MERCER ${ }^{1}$, ALBERT H. HOFSTRA $^{1}$, AND LISA L. STILLINGS ${ }^{2}$

${ }^{1}$ U.S. Geological Survey, Denver, CO, USA

${ }^{2}$ U.S. Geological Survey, Reno, NV, USA

Lithium is a high-demand, energy-critical element used in lightweight rechargeable lithium-ion batteries $[1,2]$ that is primarily produced from pegmatites and brines in arid, closed lacustrine basins [3]. Clayton Valley, NV, is the only current U.S. producer of Li from subsurface brines and hosts Libearing clays that could be a potential new resource. Locallyexposed rhyolite tuffs have been proposed as a Li source for this brine and clay deposit [4].

We investigate quartz- and feldspar-hosted melt inclusions, pumice glass, and minerals in Miocene rhyolite tuff outcrops surrounding Clayton Valley. Our goal is to characterize pre- and post-eruptive lithophile, volatile, $\mathrm{F} / \mathrm{Cl}$, and $\mathrm{Li}$ isotopic contents and mineral-melt partitioning in rhyolites using Raman, FTIR, EMP, SIMS, and LA-ICP-MS.

Preliminary results show that melt inclusion shrinkage bubbles contain extremely low $\mathrm{CO}_{2}$ contents that are not resolvable by Raman. FTIR analyses reveal that melt inclusions contain $\sim 1-7 \mathrm{wt} \% \mathrm{H}_{2} \mathrm{O}$ and $\leq 300 \mathrm{ppm} \mathrm{CO}_{2}$ corresponding to vapor saturation pressures of $\leq 250 \mathrm{MPa}(\leq 6$ $\mathrm{km}$ depth). Melt inclusions and pumice glass are trachydacite to ferroan rhyolite with ASI 1.0-1.3, Cl 500-1500 ppm and F $\sim 1000-2400 \mathrm{ppm}$. Feldspars range in composition from oligoclase to labradorite to sanidine, and biotites range from $\sim 0.45-0.7 \mathrm{X}_{\mathrm{Mg}}$ and $~ 5.0-6.3 \mathrm{IV}(\mathrm{F} / \mathrm{Cl})$. Magnetite-ilmenite pairs indicate equilibration at $\sim 710-780^{\circ} \mathrm{C}$ and $f_{\mathrm{O} 2} \sim \Delta \mathrm{NNO}+1.2$. Upcoming SIMS and LA-ICP-MS analyses will allow calculation of lithophile mineral-melt partitioning and shed light on lithophile and $\mathrm{Li}$ isotopic abundances to understand the source, concentration, and release mechanisms of $\mathrm{Li}$ in rhyolitic magmas.

[1] American Physical Society (2011) Amer Physical Soc, 24. [2] Goonan (2012) USGS Circ 1371,14. [3] Kesler et al. (2012) Ore Geol Rev, 55-69. [4] Hofstra et al. (2013) Soc Econ Geol 108, 1691-1701. 